\title{
Effect of Audit Quality on Earnings Quality: Evidence From Indonesia Stock Exchange
}

\author{
Sumiadji $^{1}$, Grahita Chandrarin ${ }^{2} \&$ Edi Subiyantoro ${ }^{2}$ \\ ${ }^{1}$ State Polytechnic of Malang, Indonesia \\ ${ }^{2}$ University of Merdeka Malang, Indonesia \\ Correspondence: Sumiadji, Accounting Department, State Polytechnic of Malang. Jln. Soekarno-Hatta, No.9 Malang \\ Jawa Timur, 65141 Indonesia.
}

Received: October 17, 2018

Accepted: January 14, 2019

Online Published: January 20, 2019

doi:10.5430/ijfr.v10n1p86

URL: https://doi.org/10.5430/ijfr.v10n1p86

\begin{abstract}
This research was conducted to test the effect of audit quality on earnings quality. Its observed data consisted of 116 annual data of manufacturing companies listed in the Indonesia Stock Exchange within 2011-2014. The proxies of audit quality are auditor size, audit tenure and audit specialization. The earnings quality was formed from the attributes of accrual quality, persistence, predictability, and income smoothing. The analysis techniques for this research involved (1) an confirmatory factor analysis to form the earnings quality and (2) multiple regression analysis to test the effect of the auditor size, audit tenure and audit specialization on earnings quality. Analysis results showed that earnings quality is formed by the attributes of persistence and predictability. Research results showed that auditor size and audit tenure have effect on earning quality, while audit specialization do not.
\end{abstract}

Keywords: audit quality, earnings quality, confirmatory factor analysis

\section{Introduction}

Earnings quality is one of the pieces of information that investors rely on to make decisions. Information of earnings given by the management through financial reports are also affected by management policies, which means that the management manages information that could be directed for certain purposes (Scott, 1997).

There are a lot of financial and accounting implementation cases of companies that directly or indirectly involve external auditors such as the Enron and WorldCom cases including several cases of public companies in Indonesia. External auditors are also considered to be less sensitive to the risks that occur in clients, less-independent, and lack of professional objectivity and responsibility which tend to affect audit quality. Based on this phenomenon, this study examines the effect of audit quality on earnings quality.

In previous research, audit quality had the proxies of several measurements, including audit firm size, audit tenure, audit industry specialization, re-presentation, litigation, accrual, and so on (Hu, 2015). Meanwhile, earnings quality had the proxies of the accrual approach (Al-Thuneibat et al., 2011; Francis and Wang, 2008; Kabir et al., 2011; Siagian and Tresnaningsih, 2011; and Wang et al., 2014) and earning respone coefficient (Ghosh and Moon, 2005; Teoh and Wong, 1993; Zakaria and Daud, 2013).

In this research, audit quality has the proxies of auditor size (the Big-4), audit tenure and audit specialization. Audit quality returned to public attention due to a number of accountancy and financial cases which indirectly involved public accountants, such as Waste Management, Enron, WorldCom, and several cases in Indonesia. Earnings quality in this research is a composite variable from the attributes of accounting earning qualities, made up of accrual quality, persistence, predictability, and income smoothing (Francis et al., 2004).

\section{Theoretical Review}

\subsection{Theoretical Framework}

Agency theory recognizes that there is a tug-of-war of interests between owners or principals and managers. The problem of information integrity appears, for which one reason is due to the information asymmetry. Investors possess limited access to sufficient information to make decisions. Beneficial behaviors become the tendency for managers who possess more information than other stakeholders (Jensen and Meckling, 1976). Information, 
including quality information on earnings, is very much needed by investors as material for making decisions. Auditors as external parties may be the ones to rely on in neutralizing conflicts of interests and reducing the information asymmetry, thereby maintaining the information integrity of financial reports (Almutairi et al., 2009; Varici, 2013). Companies may obtain economic and control benefits from auditing activities; one of these is that audits can increase information quality and earnings quality. Audits play an important role in decreasing the information asymmetry and moral hazards in order to provide certainty of information to stakeholders, so that the financial reports that are prepared by managers as agents can be relied upon.

\subsection{Literature Review and Hypothesis}

\subsubsection{Audit Quality and Earnings Quality}

Audit quality has multiple meanings. In relation to earnings quality, audit quality is the accurateness of information given by an auditor to an investor to make more accurate estimations of company value (Titman and Trueman, 1986). Palmrose (1986) affirms that audit quality is indicated by financial reports that do not present the material misstatement. The measurement of audit quality in research is derived from, among others, audit firm size (Alzoubi, 2016; Francis and Wang, 2008; Wang et al., 2014) and audit tenure (Al-Thuneibat et al., 2011; Davis et al., 2000; Gul et al., 2009; Myers et al., 2003). Earnings quality shows accurate and unbiased earnings information which can explain company performance (Bissessur, 2008). The advantage of earning quality is that it can be used to help make decisions (Dechow et al., 2010). Further, this research considers the four indicators of accounting earnings quality, namely accrual quality, persistence, predictability, and income smoothing (Francis et al., 2004).

\subsubsection{Auditor Size}

Auditor size indicates the large scale income and organization of the public accountant firm, which is now called Big 4 (including its affiliation), comprising PricewaterhouseCoopers (PwC), Deloitte Touche Tohmatsu (Deloitte), Ernst and Young (EY), and Klynveld Peat Marwick Goerdeler KPMG). Previous research had documented the correlation between audit quality being measured by a measurement proxy of a Big 4 auditor (Al-Thuneibat et al., 2011; Alzoubi, 2016; Francis and Wang, 2008; Houqe et al., 2015; Kabir et al., 2011; Wang et al., 2014; Zakaria and Daud, 2013) and the earnings quality measured by a certain proxy such as earnings response coefficient (Alzoubi, 2016; Houqe et al., 2015; Teoh and Wong, 1993; Wang et al., 2014; Zakaria and Daud, 2013), discretionary accruals (Alzoubi, 2016), and abnormal accruals (Francis and Wang, 2008; Wang et al., 2014). The Big 4 auditors have a better audit quality than small or non-Big 4 auditors arguably because large audit firms have greater resources, knowledge, technical experience, capacity, and reputation compared to small audit firms.

Research by Zakaria and Daud (2013) also found that the Big 4 auditor have a significant and positive influence on earnings response coefficient (ERC). Results of research by Alzoubi (2016) showed that the level of earnings management is significantly lower for companies that use the Big 4 firms compared to those that use non-Big 4 firms. Houqe et al., (2015) found proof that companies that hire high-quality auditors in proxy with auditor size Big 4 have a negative influence on the earnings quality in proxy with discretionary accruals and income smoothing, which means that being audited by Big 4 auditors makes the earnings quality higher. The Big 4 auditors have greater audit quality compared to non-Big 4 auditors with the argument that the Big 4 auditors possess greater staff quality, knowledge, technical experience, capacity, and reputation compared to non-Big 4 auditors. Based on the previous research results and explanation, the hypothesis was formulated as $\mathrm{H}_{1}$ : Auditor size has a positive affects on earnings quality.

\subsubsection{Audit Tenure}

Several studies have examined audit tenure with earnings quality, including (Al-Thuneibat et al., 2011; Davis et al., 2000; Ghosh and Moon, 2005; Gul et al., 2009; Johnson et al., 2002; Manry et al., 2008; Myers et al., 2003; Yazawa, 2014). There are two opinions that form the basis of the strength of the correlation between audit firm tenure and earnings quality. The first opinion is that audit firm tenure has a positive correlation with earnings quality, which is supported by the argument that a long audit firm tenure will result in the auditor having a better understanding of the client's condition. Research by Manry et al., (2008), Myers et al., (2003), and Gul et al., (2009) concluded that audit firm tenure has a negative correlation with discretionary accruals (better earnings quality). Audit firms that are continually assigned will have a sufficient understanding of the client's business, including understanding of the client's internal control structure. This is used by the auditor to design audit procedures, resulting in a higher-quality audit report. A longer audit tenure has the implication of a higher earnings quality in proxy with the earnings response coefficient (Ghosh and Moon, 2005).

The second opinion is that audit firm tenure has a negative correlation to earnings quality, an opinion supported by the 
argument that a longer audit firm tenure will reduce the level of auditor's independence. Results of research by Johnson et al., (2002) support this opinion, that as the auditor-client relationship progresses, the report quality becomes lower, which indicated by a positive correlation between tenure and earnings persistence. A long audit firm tenure can threaten the independence of an auditor, caused by a client-auditor relationship that grows closer, which can result in the increase of the discretionary accrual proxy of audit quality (Al-Thuneibat et al., 2011; Davis et al., 2000). Davis et al., (2000) concluded that audit quality decreases as an audit tenure becomes longer, because as the audit tenure becomes further extended, the client possesses a greater financial reporting flexibility. This explanation indicates that there is a correlation between audit firm tenure and earnings quality. Based on the previous research results and explanation, the hypothesis was formulated as $\mathrm{H}_{2}$ : Audit tenure has a positive affects on earnings quality.

\subsubsection{Audit specialization}

Krishnam (2003) and (Balsam et al., 2003) found that auditor with industry specialization had lower discretionary accruals than otherwise. Gul et al., (2009) examine whether auditors of industrial specialization affect the relationship between auditor tenure and earnings quality. The results show that the shorter audit tenure of auditor specialist and non-specialist industry who audit certain companies, the lower the earnings quality of the companies will be. This research supported research of Balsam et al., (2003).

Auditors who have a concentration on a certain industry and audit procedures are likely to to gain more and in-depth knowledge about the client's business and industry, so that auditors with industry specialization can work more effectively. The effectiveness of the auditor's work reflects the expertise in detecting accounting irregularities that have an impact on the quality of information. Based on the results of the research and explanation, the hypothesis to formulated as, $\mathrm{H}_{3}$ : Audit specialization has a positive affects on earnings quality.

\section{Research Method}

\subsection{Data Collection, Sample and Analysis}

Data samples were determined by purposive sampling from manufacturing companies listed in the Indonesia Stock Exchange within 2011-2014. The 116 observed data were collected from documentation. The data were obtained from annual reports published by the Indonesia Stock Exchange and other supporting data sources. This research used the confirmatory factor analysis to determine the composite variable from four earnings quality attributes, made up of accrual quality, persistence, predictability, and income smoothing (Fanani, 2011; Francis et al., 2004; Pagalung, 2006). The regression analysis was conducted to test the influence of the independent variable on the dependent variable after performing tests for normality, autocorrelation, multicollinearity, and heteroscedasticity (Santoso, 2015).

\subsection{Research Variables}

\subsubsection{Dependent Variable}

Dependent variable of this research is earnings quality. Earnings quality refers to the capability of reported earnings to reflect the actual earnings of the company, as well as the usefulness of reported earnings to predict future earnings (Bellovary et al., 2005; Francis et al., 2004). Earnings quality is determined based on the results of confirmatory factor analysis of the four attributes of earnings quality in accounting base, made up of accrual quality, persistence, predictability, and income smoothing (Fanani, 2011; Francis et al., 2004; Pagalung, 2006).

1) Accrual quality

Accrual quality refers to the amount of income which is recognized when business unit rights arises due to the delivery of goods to an outside party and costs which are recognized when the obligation arises due to the use of economic resources attached to the goods delivered (Francis et al., 2004). Accrual quality measurement using Francis et al., (2004) and Larcker and Richardson (2004) model is the standard deviation of the company's residuals from the equation model, as follows:

$$
\begin{gathered}
\frac{\mathrm{TA}_{\mathrm{jt}}}{\text { Total Asset }_{\mathrm{jt}}}=\beta_{0}+\beta_{1} \frac{\mathrm{CFO}_{\mathrm{jt}-1}}{\text { Total Asset }_{\mathrm{jt}}}+\beta_{2} \frac{\mathrm{CFO}_{\mathrm{jt}}}{\text { Total Asset }_{\mathrm{jt}}}+\beta_{3} \frac{\mathrm{CFO}_{\mathrm{jt}+1}}{\text { Total Asset }_{\mathrm{jt}}}+ \\
\beta_{4} \frac{\Delta \text { Sales }_{\mathrm{jt}}}{\text { Total Asset }_{\mathrm{jt}}}+\beta_{5} \frac{\text { Fixed Asset }_{\mathrm{jt}+1}}{\text { Total Asset }_{\mathrm{jt}}}+\beta_{6} \frac{\text { Book Value of Equity }_{\mathrm{jt}+1}}{\text { Market Value of Equity }_{\mathrm{jt}}}+\varepsilon_{\mathrm{jt}}
\end{gathered}
$$

where:

TAjt: Net income of company $j$ in the current year (-) cash flow of operating company $j$ in year $t$ 
CFOjt-1: The company's operating cash flow last year

CFOjt: The operating cash flow of company $\mathrm{j}$ in year $\mathrm{t}$

CFOjt+1: The operating cash flow of company $\mathrm{j}$ in year $\mathrm{t}+1$

Sales: Difference in sales of the company j years $\mathrm{t}(-)$ last year $\mathrm{t}-1$

Total Assetjt: Total assets of company $\mathrm{j}$ in year $\mathrm{t}$

Book Value of Equity: The nominal value of shares $(*)$ the number of shares of the company $j$ year $t+1$

Market Value of Equity: Stock market value $\left(^{*}\right)$ number of shares of company year $t$

2) Persistence

Persistence is the condition where the current period profit is a reflection of the future period and the current period. This proxy for earnings quality is shown by the coefficient value of the annual earnings regression model with the formula (Francis et al., 2004).

$$
\frac{\text { Earnings }_{\mathrm{jt}}}{\text { Outstanding of share }_{\mathrm{jt}}}=\beta_{0}+\beta_{1} \frac{\text { Earnings }_{\mathrm{jt}-1}}{\text { Outstanding of share }_{\mathrm{jt}-1}}+\varepsilon_{\mathrm{jt}}
$$

where:

Earnings jt: earning before extraordinary accounts of company $\mathrm{j}$ in year $\mathrm{t}$

Earnings jt-1: earning before extraordinary accounts of company $\mathrm{j}$ last year

Outstanding of share $\mathrm{jt}$ : Shares outstanding in company $\mathrm{j}$ in year $\mathrm{t}$

Outstanding of share jt-1: Shares outstanding in company $\mathrm{j}$ last year

The measurement of persistence is done by looking at the beta value $(\beta 1)$ of the equation above. This variable is calculated based on the estimation from 2011-2014 using the fixed effect approach.

3) Predictability

Predictability is the ability of current earnings to predict future earnings. The predictibility is proxied by using the ARI model below, which is the root of the variance of squared errors from the model (Francis et al., 2004).

$$
\frac{\text { Earnings }_{\mathrm{jt}}}{\text { Outstanding of share }_{\mathrm{jt}}}=\beta_{0}+\beta_{1} \frac{\text { Earnings }_{\mathrm{jt}-1}}{\text { Outstanding of share }_{\mathrm{jt}-1}}+\varepsilon_{\mathrm{jt}}
$$

where:

Earnings jt: earning before extraordinary accounts of company $j$ in year $t$

Earnings jt-1: earning before extraordinary accounts of company $\mathrm{j}$ last year

Outstanding of share jt: shares outstanding in company $\mathrm{j}$ in year $\mathrm{t}$

Outstanding of share $\mathrm{jt}-1$ : shares outstanding in company $\mathrm{j}$ last year

Predictability is measured by looking at the error with the formula of the root of the error variable squared

$\left(\sqrt{\left.\sigma^{2}\left(\mathbb{V}^{\prime} \mathrm{jt}\right)\right)}\right.$ of the equation above. This variable is calculated by estimating during the year, 2011-2014 using the fixed effect approach.

4) Income smoothing

Income smoothing shows the difference between companies in terms of the variability of actual earnings according to cash flow. Proxy of financial reporting information quality is resulted from the calculation of the ratio between standard deviations of earnings before extraordinary accounts per total asset divided by standard deviation of operating cash flow per total asset (Francis et al., 2004).

$$
\text { Income smoothing }=\frac{\sigma\left(\mathrm{NIBE}_{\mathrm{jt}}\right)}{\sigma\left(\mathrm{CFO}_{\mathrm{jt}}\right)}
$$

where:

NIBEjt: Net income before extraordinary accounts of company $j$ in year $t$

CFOjt: The operating cash flow of company $\mathrm{j}$ in year $\mathrm{t}$ 
This income smoothing variable data is the average data from 2011-2014.

\subsubsection{Independent Variables}

1) Auditor Size

Audit firm size indicates the Big 4 group of audit firms and/or their firm affiliates in Indonesia. This variable is measured the same way as in a research by Alzoubi (2016), using a dummy variable of 1 if the company is audited by a Big 4 audit firm and 0 otherwise.

2) Audit tenure

Audit tenure indicates the number of years in a row a company is audited by the same audit firm, as utilized by Johnson et al., (2002) and Al-Thuneibat et al., (2011).

3) Audit specialization

An auditor is said to have industry specialization if the number of companies audited by an auditing firm is more than $15 \%$ of the number of companies audited by all auditing firms in a particular industry group, measured by a dummy variable i.e 1 for auditors who have industry specialization, and 0 otherwise (Solomon, et al., 1999; Zhou and Elder, 2004).

\subsection{Analysis Techniques}

\subsubsection{Confirmatory Factor Analysis}

The main objective of confirmatory factor analysis is to explain the structure of relationships among many variables in the form of factors or latent variables or composite variables. The criteria that must be fulfilled in the confirmatory factor analysis are a) a Kaiser-Meyer-Olkin (KMO) value $\geq 0.5$ or the probability value of Bartlett's Test $<0.05, b$ ) a Measure of Sampling Adequacy (MSA) value that must be greater than $0.5, \mathrm{c}$ ) a Communalities value greater than $0.5, \mathrm{~d}$ ) only one factor or component with eigenvalues greater than 1 (Hair et al., 1998), and e) examination of the loading factor or lambda value $(\lambda)$. The loading factor shows the matching or unidimensionality of the indicators that form the variable. Indicators with loading factors $\geq 0.4$ are included in the analysis (Ferdinand, 2002) because they constitute the variable, while the attributes with loading factors $\leq 0.4$ or negative are not included in factor analysis.

\subsubsection{Regression Analysis}

The regression equation model of the research is:

$\mathrm{EQ}=\mathrm{a}+\mathrm{b} 1$ AudSize $+\mathrm{b} 2$ AudTen $+\mathrm{b} 3$ AudSpec $+\mathrm{e}$

Where:

EQ: result of the confirmatory factor analyses of the four attributes of accounting earnings quality, measured by the score factor

a: constant

b1-b3: regression coefficient

AudSize: measured with dummy variable i.e 1 for the audit firms Big 4 and/or their affiliate firms in Indonesia, and 0 otherwise

AudTen: number of years in a row that a company is audited by the same audit firm

AudSpec: measured with dummy variable i.e 1 for auditors who have industry specialization, and 0 otherwise.

e: error

\subsubsection{Hypothesis Test}

To show the effect of the independent variables on the independent variables $t$ test is employed, which level of significant smaller than $5 \%$ (sig. value $<0.05$ ). The regression models are employed to test the alternative hypothesis (Ha) is Ho: $\beta 1=0$; and Ha: $\beta 1 \neq 0$.

\section{Results And Discussion}

The summary of the confirmatory factor analysis results is shown in Table 1. In Table 1, shows that all values of $\mathrm{KMO}$ and Bartlett's Test for the variable of earnings quality are 0.500 with 0.000 significance. This indicates that factor analysis can be carried out. In the anti-image matrics, the attributes that has a low value (less than 0.5) are dropped and not included in the next stage of analysis. The values of communalities for the attributes of earnings quality are $0.538,0.788,0.786$, and 0,492 for accrual quality, persistence, predictability, and income smoothing 
respectively. The value of each attribute is used to determine the number of representative factors from the original attributes. The total of all four communality values is 2.603 . To achieve this value, there needs to be two factors or components that have eigenvalues greater than 1 , which are single factors of 1.574 and 1.029 , which is also the case for the next stages. The loading factor indicates the matching, agreement, or unidimensionality of the attributes forming the variable. Indicators with loading factors $\leq 0.4$ or negative in value are not included in the model (Ferdinand, 2002). Empirically, the four attributes of earnings quality form a single composite variable supported by two attributes, which are persistence and predictability, each with a loading factor value of 0.887 .

Results of normality testing using Normal P-Plot indicate that the data spread across a diagonal line and follow the direction of the diagonal line and supported by asymp. sig. value of one-sample Kolmogorov-Smirnov test is 0,089. Autocorrelation does not occur, as shown by a Durbin-Watson score of 2,066 that is between the value of 1,7504 and 2,2496 (between $\mathrm{dU}$ and 4-dU) and supported by asymp. sig. value of run test is $0,351(\geq 0,05)$. Data multicollinearity did not occur, as shown by a tolerance value, less than 1 , and VIF value less than 10 . Heteroscedasticity testing used a scatterplot, indicates that the data show no clear spreading pattern and the points are spread out above and below 0 on the Y axis.

Descriptive statistics indicates that auditor size, with a minimum value of 0 and maximum value of 1 with a mean of 0.5259 indicates that more companies (53\%) are audited by accounting firms that belong to major (Big 4) firms. Auditor tenure, with a minimum value of 1 and maximum value of 6 with a mean of 3.4397, indicates that there are companies that are newly audited by certain firms, or reassignment of the old audit firm after changing to a new firm. There have also been many assignments to a certain firm in a row, up to 6 times. This condition is possible because of the requirement to change audit firms from old ones to new ones after six years of audit assignment, in accordance with regulation of Finance Minister, Republic of Indonesia No.17/Menkeu.01/2008. Audit specialization, with a minimum value of 0 and maximum value of 1 with a mean of 0.0862 indicates that around $8 \%$ of companies are audited by auditor with industry specialization. Earnings quality, with a minimum value of 0,02 and maximum value of 2,67 with a mean of 0.7308 .

Table 1. Confirmatory factor analysis of earnings quality

\begin{tabular}{|c|c|c|c|c|}
\hline \multicolumn{5}{|c|}{ 1. Indicator of Earnings Quality (Stage 1) } \\
\hline \multicolumn{5}{|c|}{ A. Kaiser-Meyer-Olkin (KMO) Measure of Sampling Adequacy (MSA) } \\
\hline KMO & \multicolumn{4}{|c|}{0,500} \\
\hline Probability & \multicolumn{4}{|l|}{0,000} \\
\hline \multicolumn{5}{|c|}{ B. Anti-image Matrics } \\
\hline Variabel & $\begin{array}{l}\text { Accrual } \\
\text { Quality }\end{array}$ & Persistence & Predictability & $\begin{array}{l}\text { Income } \\
\text { Smoothing }\end{array}$ \\
\hline MSA & 0,305 & 0,499 & 0,499 & 0,550 \\
\hline \multicolumn{5}{|l|}{ C. Communalities } \\
\hline Communalities & 0,538 & 0,788 & 0,786 & 0,492 \\
\hline \multicolumn{5}{|c|}{ D. Eigenvalues for correlation matrix reduction } \\
\hline Eigenvalues & 1,574 & 1,029 & 0,971 & 0,426 \\
\hline \multicolumn{5}{|c|}{ E. Variable Matrics Component } \\
\hline Loading factor & 0,001 & 0,885 & 0,886 & $-0,070$ \\
\hline \multicolumn{5}{|c|}{ 2. Indicator of Earnings Quality (Stage 2) } \\
\hline \multicolumn{5}{|c|}{ A. Kaiser-Meyer-Olkin (KMO) Measure of Sampling Adequacy (MSA) } \\
\hline KMO & 0,500 & & & \\
\hline Probability & 0,000 & & & \\
\hline \multicolumn{5}{|c|}{ B. Anti-image Matrics } \\
\hline Variabel & & Persistence & Predictability & $\begin{array}{l}\text { Income } \\
\text { Smoothing }\end{array}$ \\
\hline MSA & & 0,500 & 0,500 & 0,556 \\
\hline \multicolumn{5}{|l|}{ C. Communalities } \\
\hline Communalities & & 0,784 & 0,786 & 0,005 \\
\hline
\end{tabular}




\begin{tabular}{|c|c|c|c|}
\hline \multicolumn{4}{|c|}{ D. Eigenvalues for correlation matrix reduction } \\
\hline Eigenvalues & 1,574 & 0,999 & 0,427 \\
\hline \multicolumn{4}{|c|}{ E. Variable Matrics Component } \\
\hline Loading factor & 0,885 & 0,886 & $-0,070$ \\
\hline \multicolumn{4}{|c|}{ 3. Indicator of Earnings Quality (Stage 3) } \\
\hline \multicolumn{4}{|c|}{ A. Kaiser-Meyer-Olkin (KMO) Measure of Sampling Adequacy (MSA) } \\
\hline KMO & & & \\
\hline Probability & & & \\
\hline \multicolumn{4}{|c|}{ B. Anti-image Matrics } \\
\hline Variabel & Persistence & Predic & \\
\hline MSA & 0,500 & 0,500 & \\
\hline \multicolumn{4}{|l|}{ C. Communalities } \\
\hline Communalities & 0,786 & 0,786 & \\
\hline \multicolumn{4}{|c|}{ D. Eigenvalues for correlation matrix reduction } \\
\hline Eigenvalues & 1,573 & 0,427 & \\
\hline \multicolumn{4}{|c|}{ E. Variable Matrics Component } \\
\hline Loading factor & 0,887 & 0,887 & \\
\hline
\end{tabular}

Results of regression analysis (Table 2) for the auditor size variable on earnings quality indicates a probability value of 0.004 , which means that auditor size has an influence on earnings quality, and thus hypothesis $\mathrm{H}_{1}$ is accepted. The resulting coefficient value of $-0,294$ (negative direction) indicates a positive influence. It can be understood that continued audit by a Big 4 audit firm increases earnings quality progressively. Results of regression testing for the audit tenure on earnings quality indicates a probability value of 0.009 , which means that a audit tenure has an influence on earnings quality, and thus hypothesis $\mathrm{H}_{2}$ is accepted. The resulting coefficient value of $-0,080$ (negative direction) indicates a positive influence. It can be understood that a longer audit assignment by the accounting firm increases earnings quality progressively. Results of regression testing for the audit specialization on earnings quality indicates a probability value of 0.121 , which means that a audit specialization has not an influence on earnings quality, and thus hypothesis $\mathrm{H}_{3}$ is not accepted.

The F statistic value of 5.387 is significant to 0,002 , which means that the independent variable has a simultaneous influence on the dependent variable. Meanwhile, the $\mathrm{R}^{2}$ value is 0.126 , which means that the contribution of the variable in forming the model is $12.6 \%$ and the remaining $87.4 \%$ is the contribution of other variables that may explain earnings quality.

The summary of regression analysis and hypothesis results is shown in Table 2.

Table 2. Summary of regression analysis and hypothesis results

\begin{tabular}{lccll}
\hline Variable & $\begin{array}{l}\text { Unstandardized } \\
\text { Coefficients }\end{array}$ & t-value & Sig & Hypothesis \\
\hline Constant & $1,138^{\mathrm{a}}$ & $9,176^{\mathrm{b}}$ & $0,000^{\mathrm{c}}$ & \\
Auditor Size & $-0,294$ & $-2,974$ & $0,004^{*}$ & $\mathrm{H}_{1}$ accepted \\
Audit Tenure & $-0,080$ & $-2,661$ & $0,009^{*}$ & $\mathrm{H}_{2}$ accepted \\
Audit Specialization & 0,283 & 1,563 & 0,121 & $\mathrm{H}_{3}$ not accepted \\
\hline
\end{tabular}

Notes: * significant $1 \%, * *$ significant $5 \%$

\section{Conclusion And Limitation}

\subsection{Conclusion}

Analysis results indicate that the formation of the variable of earnings quality is supported by the two attributes of persistence and predictability. Test results indicate that auditor size has a positive significantly influence on earnings quality. The test results imply that continued audit by a Big 4 audit firm increases earnings quality progressively. The results of this research support the results of previous research (Alzoubi, 2016; Houqe et al., 2015; Teoh and Wong, 
1993; Zakaria and Daud, 2013) that concludes that auditor size has a positive influence on earnings quality. The measurement of earnings quality in this research is different from the measurement of earnings quality in previous research. Measurement of earnings quality in this research is composed of the attributes of persistence and predictability, while in previous research, earnings quality is measured by accrual quality, including discretionary accruals (Alzoubi, 2016; Houqe et al., 2015) and earning response coefficient (Teoh and Wong, 1993; Zakaria and Daud, 2013). The results of this research support the explanation that Big 4 auditors possess better audit resources than non-Big 4 auditors. Large audit firms possess resource capacities, including staff number and quality, application of methodology and technology in carrying out audits, internal control of the audit firms, and audit procedures that are better compared to small auditor firms.

The results of this research indicate that audit tenure has a positive significantly on earnings quality. The test results imply that extended audit by the same audit firm increases the values of the earnings quality. The results of this research are in line with results of prior research (Ghosh and Moon, 2005; Gul et al., 2009; Manry et al., 2008; Myers et al., 2003), which concludes that assignment of audit firms has a positive influence on earnings quality. There is a difference in the measurement of earnings quality in this research compared to previous research. Earnings quality in previous research is measured by the decrease of discretionary accruals (Manry et al., 2008; Myers et al., 2003) and absolute discretionary accruals (Gul et al., 2009), and the increase in earnings response coefficient (Ghosh and Moon, 2005). This research does not agree with the findings of Al-Thuneibat et al., (2011) and (Yazawa, 2014) in which it was found that audit tenure negatively influenced earnings quality, as extended audit by the same audit firm decreased earnings quality. The results of this research affirm that extended or repeated audit firm assignments further gives insight into the condition of the client, allowing the accounting firm to have the chance to improve work procedures and quality, thereby increasing information quality.

The results of this research indicate that audit specialization has not influence on earnings quality. The results of this research are not support the results of previouse research that audit specialization has positive influence on earning quality that showed through the decreasing of discretionary accruals (Balsam et al., 2003; Gul et al., 2009), absolute discretionary accruals (Krishnan, 2003) and increase the earning respone coefficient (Balsam et al., 2003). Another conclusion is that independent variables have a significant and simultaneous effect on dependent variables. The strength or contribution of the variable in forming the model is still weak, which means there are still other variables that can explain earnings quality.

\subsection{Limitations and Suggestions}

The sample for this research was determined based on specific criteria purposive sampling for manufacturing companies. Consequently, the results cannot be generalized for companies other than manufacturing companies. This research only used three independent variables, i.e. auditor size, audit tenure and audit specialization, resulting in a relatively small determination coefficient value $\mathrm{R}^{2}$ of 0.124 , which means the model still call for further development. Based on this limitation, it is suggested that further research should add other variables that may affect earnings quality (persistence and predictability) such as treasury flow volatility, accrual size, sales volatility, level of debt, and operational cycles (Fanani, 2010).

The brand name of Big auditor and audit tenur become determinant factors for better information of earning quality. Which can be used by management to consider when they appoint auditor and by regulator when they make regulation concerning, particurlarly the condition of partner and accounting firm. However, the future research need to explore other measurement or proxies for auditor size in addition to auditor label, Big 4 and non-Big 4 .

\section{References}

Almutairi, A. R., Dunn, K. A., \& Skantz, T. (2009). Auditor tenure, auditor specialization, and information asymmetry. Managerial Auditing Journal, 24(7), 600-623. https://doi.org/10.1108/02686900910975341

Al-Thuneibat, A. A., Al Issa, R. T. I., \& Ata Baker, R. A. (2011). Do audit tenure and firm size contribute to audit quality?: Empirical evidence from Jordan. Managerial Auditing Journal, 26(4), 317-334. https://doi.org/10.1108/02686901111124648

Alzoubi, E. S. S. (2016). Audit quality and earnings management: Evidence from Jordan. Journal of Applied Accounting Research, 17(2), 170-189. https://doi.org/10.1108/JAAR-09-2014-0089

Balsam, S., Krishnan, J., \& Yang, J. S. (2003). Auditor industry specialization and earnings quality. Auditing, 22(2), 71-97. https://doi.org/10.2308/aud.2003.22.2.71

Bellovary, J. L., Giacomino, D. E., \& Akers, M. D. (2005). Earnings Quality: It's Time to Measure and Report. The 
CPA Journal, 75(11), 32-37.

Bissessur, S. W. (2008). Earnings quality and earnings management : the role of accounting accruals. University of Amsterdam, Rotterdam.

Davis, L. R., Soo, B., \& Trompeter, G. (2000). Auditor Tenure, Auditor Independence and Earnings Management. Working Papper.

Dechow, P., Ge, W., \& Schrand, C. (2010). Understanding earnings quality: A review of the proxies, their determinants and their consequences. Journal of Accounting and Economics, 50(2-3), 344-401. https://doi.org/10.1016/j.jacceco.2010.09.001

Fanani, Z. (2010). Analisis Faktor-faktor Penentu Persistensi Laba. Jurnal Akuntansi Dan Keuangan Indonesia, 7(1), 109-123. https://doi.org/10.21002/jaki.2010.06

Fanani, Z. (2011). Determinant Factors of Financial Reporting Quality. Jurnal Keuangan Dan Perbankan, 15(1), 23-39.

Ferdinand, A. (2002). Structural Equation Modeling Dalam Penelitian Manajemen: Aplikasi Model-model Rumit dalam Penelitian untuk Tesis Magister dan Disertasi Doktor. Semarang: Universitas Diponegoro.

Francis, J. R., \& Wang, D. (2008). The joint effect of investor protection and big 4 audits on earnings quality around the world. Contemporary Accounting Research, 25(1), 157-191. https://doi.org/10.1506/car.25.1.6

Francis, J., LaFond, R., Olsson, P. M., \& Schipper, K. (2004). Costs of Capital and Earnings Attributes. The Accounting Review, 79(4), 967-1010. https://doi.org/10.2308/accr.2004.79.4.967

Ghosh, A., \& Moon, D. (2005). Auditor Tenure and Perception of Audit Quality. The Accounting Review, 80(2), 585-612. https://doi.org/10.2308/accr.2005.80.2.585

Gul, F. A., Fung, S. Y. K., \& Jaggi, B. (2009). Earnings quality: Some evidence on the role of auditor tenure and auditors' industry expertise. Journal of Accounting and Economics, 47(3), 265-287. https://doi.org/10.1016/j.jacceco.2009.03.001

Houqe, N., Ahmed, K., \& van Zijl, T. (2015). Effects of Audit Quality on Earning Quality and Cost of Equity Capital: Evidence from India.

Hu, D. (2015). Audit Quality and Measurement: Towards a Comprehensive Understanding. Academy of Accounting and Financial Studies Journal, 19(1), 209-222.

Jensen, M. C., \& Meckling, W. H. (1976). Theory of the Firm: Managerial Behavior, Agency Costs and Ownership Structure. Journal of Financial Economics, 3(4), 305-360. https://doi.org/10.1016/0304-405X(76)90026-X

Johnson, V. E., Khurana, I. K., \& Reynolds, J. K. (2002). Audit-Firm Tenure and the Quality of Financial Reports. Contemporary Accounting Research, 19(4), 637-660. https://doi.org/10.1506/LLTH-JXQV-8CEW-8MXD

Kabir, M. H., Sharma, D., Islam, M. A., \& Salat, A. (2011). Big 4 auditor affiliation and accruals quality in Bangladesh. Managerial Auditing Journal, 26(2), 161-181. https://doi.org/10.1108/02686901111095029

Krishnam, G. V. (2003). Does Big 6 audit industry expertize constrain earnings management?. Accounting Horizons, 17, 1-16. https://doi.org/10.2308/acch.2003.17.s-1.1

Larcker, D. F., \& Richardson, S. A. (2004). Fees paid to audit firms, accrual choices, and corporate governance. Journal of Accounting Research, 42(3), 625-658. https://doi.org/10.1111/j.1475-679X.2004.t01-1-00143.X

Manry, D. L., Mock, T. J., \& Turner, J. L. (2008). Does increased audit partner tenure reduce audit quality?. Journal of Accounting, Auditing and Finance, 23(4), 553-572. https://doi.org/10.1177/0148558X0802300406

Myers, J. N., Myers, L. A., \& Omer, T. C. (2003). Exploring the term of the auditor-client relationship and the quality of earning. The Accounting Review, 78(3), 779-799. https://doi.org/10.2308/accr.2003.78.3.779

Pagalung, G. (2006). Earning Quality: Determinant Factors and Economic Consequences. Simposium Nasional Akuntansi 9 Padang, 1-26.

Palmrose, Z.-V. (1986). Audit Fees and Auditor Size: Further Evidence. Journal of Accounting Research, 24(1), 97-110. https://doi.org/10.2307/2490806

Santoso, S. (2015). Menguasai Statistik Parametrik: Konsep dan Aplikasi dengan SPSS. Jakarta: PT Alex Media Komputindo. 
Scott, W. R. (1997). Financial Accounting Theory. Prentice Hall International.

Siagian, F. T., \& Tresnaningsih, E. (2011). The impact of independent directors and independent audit committees on earnings quality reported by Indonesian firms. Asian Review of Accounting, 19(3), 192-207. https://doi.org/10.1108/13217341111185128

Solomon, I., Shields, M. D., \& Whittington, O. R. (1999). What Do Industry-Specialist Auditors Know?. Journal of Accounting Research, 37(1), 191-208. https://doi.org/10.2307/2491403

Teoh, S. H., \& Wong, T. J. (1993). Perceived Earnings Auditor Response Quality and the Coefficient. Accounting Review, 68(2), 346-366.

Titman, S., \& Trueman, B. (1986). Information quality and the valuation of new issues. Journal of Accounting and Economics, 8(2), 159-172. https://doi.org/10.1016/0165-4101(86)90016-9

Varici, I. (2013). The Relationship between Information Asymmetry and the Quality of Audit: An Empirical Study in Istanbul Stock Exchange. International Business Research, 6(10), 132-140. https://doi.org/10.5539/ibr.v6n10p132

Wang, C. C., Kung, F. H., \& Lin, K. H. (2014). Does audit firm Size Contribute to audit quality? Evidence from two emerging markets. Corporate Ownership and Control, 11(2 A), 96-107. https://doi.org/10.22495/cocv11i2p8

Yazawa, K. (2014). Does Long Audit Partner Tenure Decrease Earnings Quality? Evidence from Japan, 27/11/2015(3), 1-40.

Zakaria, N. B., \& Daud, D. (2013). Does Big 4 affect the earnings response coefficient (ERC)? evidence from malaysia. Journal of Modern Accounting and Auditing, 9(9), 1204-1215.

Zhou, J., \& Elder, R. (2004). Audit quality and earnings management by seasoned equity offering firms. Asia-Pacific Journal of Accounting and Economics, 11(2), 95-120. https://doi.org/10.1080/16081625.2004.10510638

\section{Appendix}

Table 3. Descriptive statistics

\begin{tabular}{lccccc}
\hline & $\mathrm{N}$ & Minimum & Maximum & Mean & Std. Deviation \\
\hline Auditor Size & 116 & 0.00 & 1.00 & 0.5259 & 0.50150 \\
\hline Audit Tenure & 116 & 1.00 & 6.00 & 3.4397 & 1.68000 \\
\hline Audit Specialization & 116 & 0.00 & 1.00 & 0.0862 & 0.28189 \\
\hline Earnings Quality & 116 & 0.02 & 2.67 & 0.7308 & 0.55863 \\
\hline Valid N (listwise) & 116 & & & & \\
\hline
\end{tabular}

Table 4. Model summary ${ }^{\mathrm{b}}$

\begin{tabular}{lccccc}
\hline Model & $\mathrm{R}$ & $\mathrm{R}$ Square & $\begin{array}{c}\text { Adjusted } \\
\mathrm{R} \text { Square }\end{array}$ & $\begin{array}{c}\text { Std. Error of the } \\
\text { Estimate }\end{array}$ & Durbin-Watson \\
\hline 1 & $0.355^{\mathrm{a}}$ & 0.126 & 0.103 & 0.52917 & 2.066 \\
\hline a. Predictors: (Constant), Audit Specialization, Audit Tenure, Auditor Size \\
\multicolumn{4}{l}{ b. Dependent Variable: Earnings Quality } \\
\hline
\end{tabular}

Table 5. ANOVA ${ }^{\mathrm{a}}$

\begin{tabular}{llccccc}
\hline Model & Sum of Squares & Df & Mean Square & F & Sig. \\
\hline \multirow{2}{*}{1} & Regression & 4.525 & 3 & 1.508 & 5.387 & $0.002^{\mathrm{b}}$ \\
\cline { 2 - 6 } & Residual & 31.362 & 112 & 0.280 & & \\
\cline { 2 - 5 } & Total & 35.888 & 115 & & & \\
\hline \multicolumn{7}{l}{ a. Dependent Variable: Earnings Quality } \\
b. Predictors: (Constant), Audit Specialization, Audit Tenure, Auditor Size \\
\hline
\end{tabular}


Table 6. Coefficients ${ }^{\mathrm{a}}$

\begin{tabular}{|c|c|c|c|c|c|c|c|c|}
\hline \multirow{2}{*}{\multicolumn{2}{|c|}{ Model }} & \multicolumn{2}{|c|}{$\begin{array}{l}\text { Unstandardized } \\
\text { Coefficients }\end{array}$} & \multirow{2}{*}{$\begin{array}{c}\text { Standardized } \\
\text { Coefficients }\end{array}$} & \multirow[t]{2}{*}{$\mathrm{t}$} & \multirow[t]{2}{*}{ Sig. } & \multicolumn{2}{|c|}{$\begin{array}{l}\text { Collinearity } \\
\text { Statistics }\end{array}$} \\
\hline & & $\mathrm{B}$ & Std. Error & & & & Tolerance & VIF \\
\hline \multirow[t]{4}{*}{1} & (Constant) & 1.138 & 0.124 & & 9.176 & 0.000 & & \\
\hline & Auditor Size & -0.294 & 0.099 & -0.264 & -2.974 & 0.004 & 0.988 & 1.012 \\
\hline & Audit Tenure & -0.080 & 0.030 & -0.242 & -2.661 & 0.009 & 0.946 & 1.057 \\
\hline & Audit Specialization & 0.283 & 0.181 & 0.143 & 1.563 & 0.121 & 0.936 & 1.069 \\
\hline
\end{tabular}

a. Dependent Variable: Earnings Quality

Table 7. One-sample kolmogorov-smirnov test

\begin{tabular}{llc}
\hline & & $\begin{array}{c}\text { Unstandardized } \\
\text { Residual }\end{array}$ \\
\hline $\mathrm{N}$ & \multicolumn{1}{c}{116} \\
\hline Normal Parameters ${ }^{\mathrm{a}, \mathrm{b}}$ & Mean & 0.0000000 \\
\cline { 2 - 3 } & Std. Deviation & 0.52222187 \\
\hline Most Extreme Differences & Absolute & 0.077 \\
\cline { 2 - 3 } & Positive & 0.077 \\
\cline { 2 - 3 } & Negative & -0.071 \\
\hline Test Statistic & & 0.077 \\
\hline Asymp. Sig. (2-tailed) & & $0.089^{\mathrm{c}}$ \\
\hline a. Test distribution is Normal. & \\
\hline b. Calculated from data. & \\
\hline \multicolumn{2}{c}{ c. Lilliefors Significance Correction. } \\
\hline
\end{tabular}

Table 8. Runs test

\begin{tabular}{lc}
\hline & $\begin{array}{c}\text { Unstandardized } \\
\text { Residual }\end{array}$ \\
\hline Test Value $^{\mathrm{a}}$ & 0.05971 \\
\hline Cases $<$ Test Value & 58 \\
\hline Cases $>=$ Test Value & 58 \\
\hline Total Cases & 116 \\
\hline Number of Runs & 54 \\
\hline$Z$ & -0.933 \\
\hline Asymp. Sig. (2-tailed) & 0.351 \\
\hline a. Median & \\
\hline
\end{tabular}




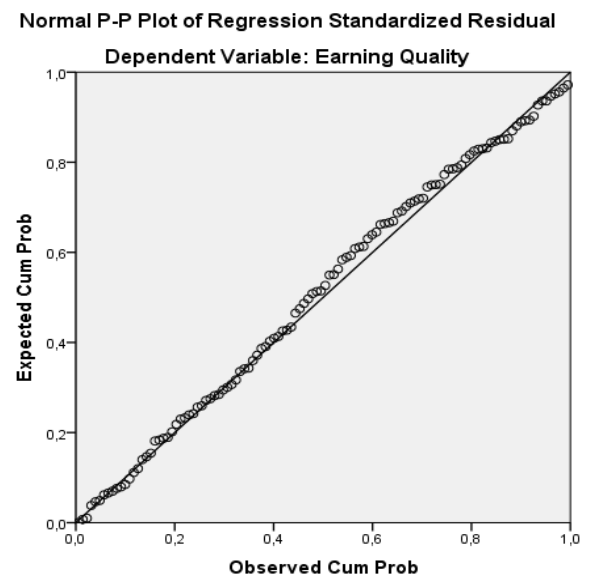

Figure 1

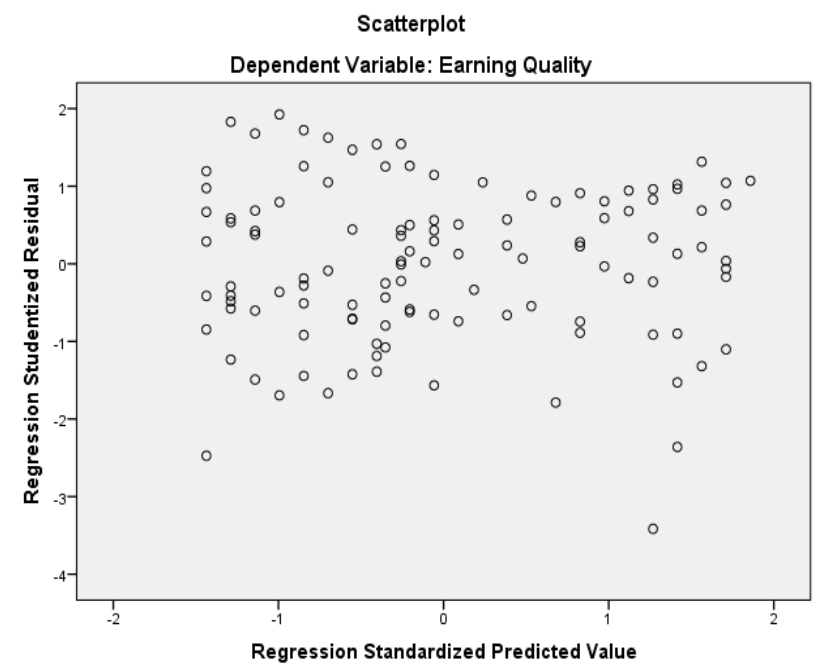

Figure 2 